\title{
TRANSACTIONS
}

\section{OF THE \\ NEW YORK SURGICAL SOCIETY.}

Stated Mecting, April 11, 1906.

Grorge, E. Briwer, M.D., in the Chair.

\section{VANISHING TUMOR OF THE PYLORUS.}

Dr. Howaro Lilinetina presented a man, 40 years old, who was admitted to Mount Sinai Hospital on February 5, - 1906, in the service of Dr. Alfred Meyer. He was pale and emaciated, and had frequent attacks of vomiting. An inspection of the abdomen showed waves of violent peristalsis extending from the upper left side to the right iliae region. The abdomen was rigid. There was practically no temperature. A bloodcount showed only profound ancmia. After an enema there was a fair movement of the bowels, with eonsiderable gas, and the peristaltic movenents eeased.

As the symptoms seemed to point to an intestinal obstruetion, a small ineision was made in the right iliae region, the plaee where the peristalsis seemed to eome to a stop. Nothing abnornal was found there, but the palpating finger detected a tumor of the pylorie region, so a second incision was made higher up, which revealed a tumor of the pylorus fully as large as a duck's egg. It was frecly movable, and was regarded as a earcinoma. The man's condition at the time was such that nothing could be done but a posterior gastro-enterostomy, which was eompleted by the suture method.

Sixteen days after the original operation, the patient's abdomen was again opened through the cicatrix of the upper 
wound, with the intention of performing pylorectomy. During that brief period, however, the tumor of the pylorus had entirely disappeared. Not a vestige of it remained, and there was only the slightest suspicion of thickening around the pylorus. No treatment had been given in the interim.

Dr. Charles N. Dowd said that several years ago he reported before the Soeiety a case which was almost the exact counterpart of the one shown by Dr. Lilienthal, but that the subsequent history of this ease was also worthy of attention. The patient, a young man, had all the signs of pylorie obstruction, with extreme emaciation. Upon opening the abdomen a firm tumor of the pylorus was found, abont as large as a hen's egg. It appeared to be malignant, bnt on aecount of the patient's extremely weak condition a gastro-enterostomy was done, in the expectation of doing a pylorectomy at a later time. At the subsequent operation, however, no signs of the tumor of the pylorus could be found, and therefore the pylorcetomy was not done. About eighteen months later the man died from perforation of the stomach, duc to a diffuse cancer of the pylorus, and on autopsy all the tissues in the vicinity were found involved by eanecrous infiltration.

Dr. Dowd said that it was diffeult to explain these temporary pyloric tumors, but suggested that œdema which was due to the presence of an ulcer, or possibly a beginning cancer, must be an important element in their formation.

Dr. Artilur L. Fisk said that six year's ago, he was asked to sce a gentleman who was supposed to have cancer of the pylorus. The man was greatly emaciated, very feeble, and eachectic, and had a tumor in the epigastrium the size of an adult fist. The diagnosis was made by two of the best physicians in New York City, and the family were so informed. No operation was performed; the tumor gradually disappeared, and the man is living still, in excellent health, at the age of 84 . Nothing ean be palpated in the epigastrium which is suggestive of a tumor, or even thiekening.

Dr. Georgi: E. Brewer said that in Dr. Dowd's case the lesion was perhaps a pylorie ulcer, with the subsequent development of cancer. In comection with the cases that had been spoken of, Dr. Brewer said he wished to report a cise of tumor of the sigmoid which, upon operation, he regarded as an in- 
filtrating carcinoma. The condition seemed to be inoperable, and he limited himself to a colostomy. Eighteen months later the man returned to have his colostomy wound elosed, and upon opening the abdomen it was found that the supposed careinomatous mass had entirely disappeared. It was probably a gummatous tumor, as the patient subsequently gave a history of persistent headaches, which had disappeared under the use of potassium iodide.

DR. LnhentunL said that his patient had received no anti-syphilitic medication whatever after the operation. The mass at the pylorus might possibly be explained by assuming that the man had an ulecr, with a minte perforation and odema, and the pouring out of an enormous quantity of lymph. The gross appearanee of the mass, however, was eertainly that of eareinoma.

As a possible aid in the diagnosis of these eases, Dr. Lilienthal said, the fact should not be lost sight of that large eareinomatous growths in the peritoneal region usually, though not always, invacled neighboring organs. If suffieient time had elapsed to allow the growth to attain consiclerable size, the probabilities were that there would be adlesions, and that adjacent struetures would be invaded. In the absenee of sueh manifestations, the malignant nature of the growth might be looked upon as doubtful.

\section{ACU'TE DIFFUSE SUPPURATIVE PERITONITIS.}

Dr. BENJAin 'T. 'luton presented a boy of 7 years, who, while being treated at the Willard Parker Hospital for scarlet fever, on the fourth day of that discase cleveloped acute abdominal pain, followed by vomiting. He was kept under observation for twenty-four hours, and then transferred to Bellevue, the ease being regarded as one of aeute peritonitis.

$\Lambda$ the time of his admission to Bellevue the abdomen was very much distended, with marked rigiclity and tympanites, and general abdominal pain. The temperature was 102.8 , pulse 1 30 . The vomitus consisted of greenish material. An immediate operation was clone, and on opening the abdomen in the median line, free pus was found throughout the peritoncal cavity. The appendix was found free from adhesions and not maikedly enlargerl. It was not removed. On the left side of the abdomen an abseess was found localized among 
coils of intestinc. The abdomen was irrigated and drained. The patient's condition was so bad that he almost died on the table. He was plaeed in the Fowler's position. Four hours after the operation the boy's temperature was 101.8; pulse, 142; respiration, $5^{2}$. On the following morning his eondition had remarkably improved, and from that time on the ease went on to uninterrupted recovery. Five wecks had clapsed since the operation.

THE TREATMENT OF DIFFUSE SUPPUIRATIVE PERITONITIS IOLLOWING APPENDICITIS.

Dr. Lucius W. Hotcinkss read a paper with the above title (for which see page 197).

Dr. Joseril A. BlAke said the method of treatment of these cases, as outlined by Dr. Hotchkiss, was practically the same as that followed in his own work, and, so far as he knew, it was the best way. The speaker said he always inserted the drain into the peritoncal cavity, so as to carry off all excess of fluid. The work of Oclisner in this field of surgery was very valuable and instructive, and was confirmatory of Dr. Hotchkiss' method of treatment. Ochsner employed no drainage, and the diseased appendix was left in; if that organ was removed there was even less need of drainage. The modern tendency was to drain as little as possible, as it was well known that the introduction of a drain into the peritoneal cavity was fraught with great danger, and in the old days, when frec diainage was resorted to, the patients almost invariably clied.

The method of drainage recently suggested by Murphy, Dr. Blake said, was in some respects similar to the older form of treatment, its object being to remove the products of inflammation in the peritoneal eavity through an opening in the lower part of the abdomen. This to a certain extent did away with the necessity for the ordinary methods of drainage, but the same result of removing these products of inflammation eould be accomplished by proper irrigation. The introcluction of a certain quantity of hot saline solution into the abdominal cavity acted as a stimulant, but if continued for too long a time it was apt to produec shock. It should not be continued for over five minutes at a time. The amount of ether given these patients 
should also be limited. After the peritoneal cavity had been cleansed as thoroughly as possible, a minimum amount of drainage should be employed, but if neerotic material had to be left belind in the abdomen, it should be isolated and drained.

Dr. Blake said that since he had used solutions of magnesium sulphate in the spinal canal, and had become better aequainted with the effects of the drugg, he harl felt less inclined to introduce it into the intestine following operation. In ecrtain conditions it might fail to produce an cvacuation, and by absorption might give rise to poisonous effects. He had reently heard of such a case in Boston.

Dr. Litherrisu, said that at the outset it was important to define what constituted peritonitis. 'The mere fact that pus was occupying every crack and corncr of the peritoneal cavity did not constitute a peritonitis. The presence or absence of other symptoms was important; namely, whether the tongue was chy or moist, whether there was paralysis of the intestine, whether the patient was elear in his mind, whether there was a septic nephritis, ctc.

Discussing the anatomical phase of the subject, Dr. Lilienthat saicl it haid appeared to him that the so-called cliffuse peritonitis was a less scrious condition than that form in which there were multiple absesses throughout the peritoneum. He recalled one case, however, in which he opened five such absecsses with good result.

Dr. Lilienthal saicl that most surgeons were in accord that in the treatment of septic peritonitis the abdominal incision should be a small one, a minimum amount of the anesthetic should be used, and the offending cause, if possible, should be removed. There was a difference of opinion as to whether the abdominal cavity should be irrigated or not. In one case, an irrigation continued for five minutes might prove a dangerous procedure, while in another irrigation for even a single minute would be contraindicated. Personally, the speaker said, he did not irrigate at all, no matter how much pus was there. Hc recallecl one case where on opening the abdomen he found a gangrenous appendix, with an enormous quantity of free pus in the peritoneal cavity. The appenclix was removed, and deep chainage introduced through the pelvis. The abdominal eavity was not irrigated, but with every inspiration there was a flow 
of pus through the tube. The patient made a good recovery. Dr. Lilienthal said that in spite of the good results obtained by Dr. Blake and others who favored irrigation in these cases, he thought their results would be still better if they dispensed with irrigation. The spcaker said he was formerly very enthusiastic in his advocaey of the value of irrigation, but now he was opposed to both irrigation and drainage, restricting the latter to those cases where the Fowler position was used, as there he thought the drain prevented the formation of secondary abscesses in the pelvis. With that one exeeption, and perhaps even without it, he was in favor of dispensing with drainage entirely, restricting himself to sewing up the greater part of the wound and putting in a drain just inside of the peritoneumjust enough to get rid of the overflow.

Dr. Lilienthal said it was the practice in his service at the hospital to take a culture from the free pcritonenl fluid in these cases, and if the streptoeoccus was found, the case was regarded as a much graver one than were the usual forms of peritonitis.

DR. Fisk said that Mr. Herbert J. Paterson, in his Hunterian Lecture, published in the London Lancel, March 3, 1906, discussed this very question, and advocated removing the cnuse of the trouble, sponging out the space behind and above the liver only, sucking out, with as little disturbance as possible to the intestines, any fluid in Douglas' cul-de-sac, and establishing early intestinal peristalsis.

Dr. Fisk said that among the earlier cases of this kind that were operated on at the Massaehusetts General Hospital, when he was an interne there, irrigation was done hourly for many hours, and most of the patients died. The spcaker said he had entirely discarded irrigation; that he now removed the appendix, very gently but thoroughly dried out the pelvis with gauze sponges wrung out in warm salt solution, and then inserted a eigarette drain to the stump of the appendix. The results of that method had thus far been very satisfactory. The Fowler position was maintained for some days.

DR. Hotcikiss said the entire diseussion centred about one point, which was the logical crux of the situation, and that was, whether irrigation of the peritoneal cavity was beneficial or harmful? Whether it was wise in these extensive eases to remove, by irrigation, part of the highly albuminous exudate, 
which was relatively slow of absorption, and replace it by saline solution, which was more rapid of absorption? The insertion of a drainage tube into the pelvic eavity of course removed the pus that was there at the time, but in the eourse of a very few hours, the drainage would be elosely limited by adhesions and we eould not drain the peritoneal eavity within.

Personally, Dr. Hotehkiss said, he did not regard the irrigation as all important. There is bound to be considerable differenee of opinion anong surgeons as to the method of treating these enses. If we eould safely omit the irrigations, well and good. It had been demonstrated in his own experienee that we could omit drainage, if we would wash out some of the purulent fluid. Whether both drainage and irrigation eould properly be omitted in some of these eases was still an unsettled question.

Dr, LiLien'ilat asked Dr. Hotchkiss whether he would resort to drainage in a case of peritonitis, with free pus in the peritoneal cavity and a nccrotie abscess surrounding the appendix? Personally, he thought that such an abscess should be drained. He was willing, however, and he intended in his future cases to omit pelvic drainage; he was inelined to agree with the reader of the paper that irrigation was nothing more than one form of drainage.

Dr. Hotchisss, in reply to Dr. Lilienthal, said that if there was a localized necrosis which could not be removed, it should be packed until it eame away. In cases where the gangrenous appendix could be removed, entirely and cleanly, he did not drain at all.

- Dr. Hotcirkiss said it was generally agreed that at least a great part of the exudate in these eases was the result of a conservative proeess on the part of nature to repair the damage that had been done, and it was not only wise to retain it there, but it was impossible to entirely wash it away. By rapid irrigation, he thought we washed away some of the highly albuminous purulent fluid, whieh was slow of absorption, and sometimes harmful, and replaeed it by a weaker solution, whieh was more rapidly absorbed. 